\title{
The technique of selective laser sintering (SLS) in the design high-porous ceramic implants
}

\author{
Technika selektywnego spiekania laserowego \\ w projektowaniu implantów z ceramiki wysokoporowej
}

\author{
BARBARA STANIEWICZ-BRUDNIK \\ ANDRZEJ STWORA \\ JOANNA MASZYBROCKA \\ GRZEGORZ SKRABALAK \\ ELŻBIETA BACZZEK *
}

\author{
DOI: $10.17814 /$ mechanik.2016.5-6.76 \\ Międzynarodowa Konferencja IMT 2016
}

\begin{abstract}
Most of the metal and ceramic implants (eg. dental implants, ENT implants) can be performed by SLS technique with a proper initial materials and technological process parameters. Attention should be drawn to the process prerequisites like chemical composition of powder, particle size distribution and shape, the optical properties of the material, its thermal conductivity and the type of protective atmosphere. Spatial model of the implant with a porosity of $80 \%$ based on the MatLab program was developed.
\end{abstract}

KEYWORDS: SLS technique, 3D implant model, ceramic implant, submicrocrystalline sintered corundum

Większość implantów metalowych i ceramicznych (np. implanty stomatologiczne, wszczepy otolaryngologiczne) można wykonać techniką SLS przy odpowiednim doborze materiałów i parametrów technologicznych procesu. Należy zwrócić uwage na warunki wstępne procesu, takie jak: skład chemiczny proszku, rozkład wielkości ziaren i ich kształt, właściwości optyczne materiału i jego przewodnictwo cieplne oraz rodzaj zastosowanej atmosfery ochronnej. Opracowano model przestrzenny implantu o porowatości $80 \%$ w oparciu o program MatLab.

SŁOWA KLUCZOWE: technika SLS, model przestrzenny implantu, implant ceramiczny, submikrokrystaliczny korund spiekany

Due to the aging of the European population, increased number of traffic accidents and lifestyle diseases (including cancer) and limited transplantation possibilities, more and more attention is paid to the possibility of using bioactive ceramic implants received by using new techniques (SLS, SLM, EBM). The Engineering Ceramics in Europe and USA report shows that the market for the implants using the ceramic-ceramic connection has increased rapidly from 2009 to 2012 (approx. 20\%). In Lesser Poland (Małopolska) about 7,500 implants (including hip replacements, knee prostheses, spinal stabilizers, plates, screws, bone implants) were used annually. The technique of selective laser sintering is one of the latest techniques for the production of

\footnotetext{
${ }^{*}$ Dr inż. Barbara Staniewicz-Brudnik, prof. IZTW (barbara.brudnik@ios.krakow.pl), mgr inż. Andrzej Stwora (andrzej.stwora@ios .krakow.pl), dr inż. Grzegorz Skrabalak (grzegorz.skrabalak@ios.krakow.pl), mgr inż. Elżbieta Bączek (elzbieta.baczek@ios.krakow.pl) - Instytut Zaawansowanych Technologii Wytwarzania; dr Joanna Maszybrocka (joanna.maszybrocka@us.edu.pl - Instytut Nauki o Materiałach, Wydział Informatyki i Nauki o Materiałach, Uniwersytet Śląski
}

models, prototypes and series of products consisting of merging layers of powder using laser light [1]. To date, highporous materials were derived by the techniques like chemical foaming, frothing mechanically or by mapping porous matrix, etc.

The technique of selective laser sintering by the preliminary sintered powder in suitable granulation is the most stable method for obtaining high-porous materials at predetermined, stable physical and mechanical properties, not yet used in Poland in relation to the bioceramic materials.

\section{Literature analysis}

Selective laser sintering process of different materials is the most commonly used due to their ability to produce complex parts with complex geometry without having to use additional equipment. This technique allows to obtain a product with the physical, chemical and mechanical properties different from the properties of the initial material components in a fast way, with fixed repetition and greater accuracy. From a historical point of view at the beginning of the development of this technology metals and their alloys, then plastics were used. Last decade brought much interest in much more difficult material like ceramics. Analysis of literature leads to the conclusion that the most of the ceramic implants (eg. on the prosthetic eye, dental implants, implants transdermal stabilizers of the spine, hip replacements and knee joint prostheses) [1], can be manufactured by SLS technique with the proper selection of materials and technological parameters of the process.

However, attention should be paid to the prerequisites of the process like: the chemical composition of the powder grain size distribution (below $40 \mu \mathrm{m}$ ) and shape (preferably spheroidal), the optical properties of the material and its thermal conductivity, the type of laser $\left(\mathrm{CO}_{2}, \mathrm{Nd}: \mathrm{YAG}\right.$, $\mathrm{Nd}$ : YAG fiber) and the type of protective atmosphere (nitrogen, argon, oxygen, vacuum). Laser sintering techniques can be classified into three categories defining the connection mechanism: solid-state sintering, sintering of the liquid phase and melting-solidification process.

Solid state sintering relates to a thermally active transport of materials by reducing the surface energy of the aggregated particles. This process is free running at $50 \%$ of the melting point. In the second case, the sintering temperature is higher, because under the melting temperature a local liquid phase that affects capillary action to the solid particles by combining them together is formed.

Unfavorable phenomena in the process of SLS include increased residual stress of ceramic pieces because of the 
speed of the processes. This is due to scanning speed and distance between the laser spots. The consequence of obtaining extremely high temperatures of SLS process in a very short time is formation of SLS phases being far away from thermodynamic equilibrium. It causes a rapid transition of the high-temperature phase to transition phases which can be also present at room temperature. Atmosphere used in the sintering process (nitrogen, argon, oxygen, vacuum) may affect the chemical reactions with the sintered material. This is particularly important when introducing oxygen or nitrogen, as the partial pressure of oxygen affects the thermodynamic equilibrium of oxidation processes and reduction of sintered material. Tab. I lists types of SLS devices, work condition of devices and types of sintered ceramics published in literature in 2015.

TABLE I. Types of devices SLS, the parameters of work and the types of sintered ceramic materials

\begin{tabular}{|c|c|c|}
\hline Article Equipment & Working conditions & Material \\
\hline $\begin{array}{l}\text { Rapid Prototyping Journal } 21 \\
\text { (2015): pp. } 201 \div 206[2] \\
\text { LENS }\end{array}$ & $\begin{array}{c}\text { Laser YAG: Nd3+, } \\
\text { Power } 350 \mathrm{~W} \\
\text { Laser spot } 220 \mu \mathrm{m} \\
\text { Laser scaning } 5 \mu \mathrm{m} / \mathrm{sec}\end{array}$ & $\mathrm{Al}_{2} \mathrm{O}_{3}$ \\
\hline $\begin{array}{c}\text { Applied Surface Science } 336 \\
\text { (2015): pp. 59:66 [3] } \\
\text { Solar Laser SystemLQ929 }\end{array}$ & $\begin{array}{c}\text { Laser YAG: Nd3+, } \\
\text { Laser spot } 200 \mu \mathrm{m} \\
\text { Laser scaning } \\
110,400,550 \mu \mathrm{m} / \mathrm{sec}\end{array}$ & $\begin{array}{c}\mathrm{MgO} \\
\mathrm{MgF}_{2} \mathrm{O}_{4} \\
\mathrm{MgAl}_{2} \mathrm{O}_{4}\end{array}$ \\
\hline $\begin{array}{l}\text { Mat.Sci.Eng. A628 (2015): } \\
\text { pp. } 188 \div 197[4] \\
\text { No data }\end{array}$ & $\begin{array}{l}\text { Laser YAG: Nd3+, } \\
\text { Power } 100 \div 400 \mathrm{~W} \\
\text { Laser scaning } \\
1000-7000 \mu \mathrm{m} / \mathrm{s}\end{array}$ & $\mathrm{AISi}_{10} \mathrm{Mg}$ \\
\hline
\end{tabular}

\section{Spatial model of the implant}

Chosen model belongs to the group of triply periodic minimal surface and is described by the equation:

$$
\begin{gathered}
\mathrm{k}_{1} \cdot[(\sin (\mathrm{x}) \cdot \sin (\mathrm{y}) \cdot \sin (\mathrm{z})+\sin (\mathrm{x}) \cdot \cos (\mathrm{y}) \cdot \cos (\mathrm{z})+\cos (\mathrm{x}) \\
\sin (\mathrm{y}) \cdot \cos (\mathrm{z})+\cos (\mathrm{x}) \cdot \cos (\mathrm{y}) \cdot \sin (\mathrm{z})]+\mathrm{k}_{2} \cdot[\cos (4 \mathrm{x})+ \\
\cos (4 \mathrm{y})+\cos (4 \mathrm{z})]+\mathrm{k}_{3}=0
\end{gathered}
$$

where: $x, y, z$ are versors and $k_{1}, k_{2}, k_{3}$ are parameters determining the porosity of the unit structure.

Elementary cell of the structure was shown in Fig. 1 a. The parameters $k_{1}, k_{2}, k_{3}$ are chosen in such way that the obtained porosity of the structure was $\mathrm{Vv}=80 \%$. The percentage was defined as the ratio of the material volume to the total volume of cuboid of the surrounding modeling area (assuming that the area of the modeling will provide a cube with dimensions of $10 \times 10 \times 10 \mathrm{~mm}$ ). The modeling process was carried out in the original script MatLab. The threedimensional mesh as a set of coordinates of the vertices and the set of elements that define the topology of the grid has been exported to .obj format. The final model is shown in Fig. $1 b$. a)

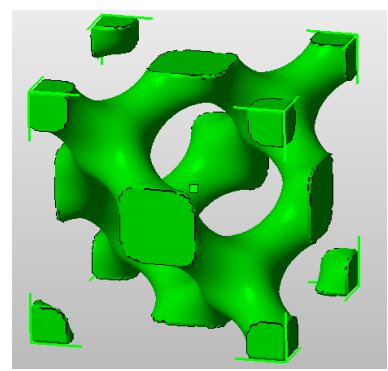

b)

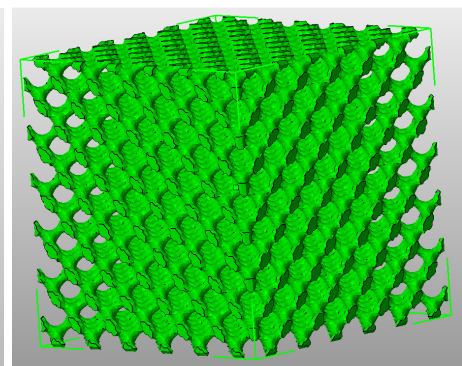

Fig. 1. 3D model of the implant: a) unit cell, b) model of $\mathrm{Vv}=80 \%$ porosity

\section{Research material}

The research material for receiving the implant was submicrocrystalline sintered corundum (cubitron). It was pretested for physical, chemical, mechanical and biological properties at earlier work $[5 \div 7]$. Selected properties of cubitron are summarized in Tab. II.

TABLE II. Selected properties of submicrocrystaline sintered corundum grains (cubitron)

\begin{tabular}{|l|c|}
\hline Properties & Results \\
\hline Density, $\mathrm{g} / \mathrm{cm}^{3}$ & 3.884 \\
\hline Microhardness, GPa & 21.5 \\
\hline Flexural strength, MPa & 140 \\
\hline Young modulus, GPa & 350 \\
\hline Wettability by FB1 $\mathrm{glass}$ & $<35^{\circ}$ \\
\hline Grain granulation, $\mu \mathrm{m}$ & $\mathrm{D}_{50} 40 \mu \mathrm{m}$ \\
\hline Specific area $\mathrm{S}_{\mathrm{BET}}, \mathrm{m}^{2} / \mathrm{g}$ & 12.8 \\
\hline
\end{tabular}

\section{Conclusions}

Selective laser sintering is a modern technique that creates the possibility of obtaining a stable ceramic with a very high porosity, the programmed architecture of pores and interporous connections [8]. On the basis of literature discernment it can be said that the technological parameters of the process of SLS have changed in the following areas: type $\mathrm{CO}_{2}$ laser, $\mathrm{Nd}$ : YAG, $\mathrm{Nd}$ : YAG fiber, laser power 3-600 W, scan speed 6-1257 $\mathrm{mm} / \mathrm{s}$, the distance between the lines $2-300 \mu \mathrm{m}$, the thickness of $20-60 \mu \mathrm{m}$.

On grounds of performed analysis the following operating parameters for EOS EOSINT $250 \mathrm{XT}$ to obtain the initial implant model have been suggested: power $\mathrm{CO}_{2}$ laser 20 , $60,100 \mathrm{~W}$, scanning speed from 1000 to $1250 \mu \mathrm{m} / \mathrm{s}$, the distance between lines $150 \mu \mathrm{m}$, the thickness $50 \mu \mathrm{m}$, spot diameter $100 \mu \mathrm{m}$.

The research was carried out in the frame of Statutory Work of The Institute of Advanced Manufacturing Technology DS.15-1.5.1.

\section{LITERATURE}

1. Fwu-Husing Liu „Synthesis of biomaterial composite scaffolds by laser sintering: Mechanical properties in vitro bioactivity evalua-

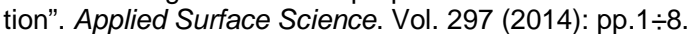

2. Niu F. et al. „Effect of second-phase doping on laser deposited $\mathrm{Al}_{2} \mathrm{O}_{3}$ ceramics". Rapid Prototyping Journal. Vol. 21, No. 2 (2015): pp. $201 \div 206$.

3. Garcia I.V. et al. „Laser sintering of magnesia with nanoparticles of iron oxide and aluminum oxide". Applied Surface Science. Vol.

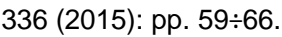

4. Qiu C. et al. „Influence of processing conditions on strut structure and compressive properties of cellular lattice structure fabricated by SLM". Materials Science Engineering A. Vol. 628 (2015): pp. $188 \div 197$.

5. Staniewicz-Brudnik B. et al. „Biocomposites with submicrocrystalline sintered corundum and bioglass system as a substrates and their structural and physical properties". Optica Applicata. Vol. 42, No. 2 (2012): pp. $387 \div 397$.

6. Jeagerman Z., Ślósarczyk A. „Gęsta i porowata bioceramika korundowa w zastosowaniach medycznych". Kraków: AGH Uczelniane Wydawnictwa Naukowo-Dydaktyczne, 2007.

7. Staniewicz-Brudnik B., Szarska S., Gamrat K. „The influence of mechanochemical treatment of sintered submicrocrystalline corundum substrates on the structure of bioglass composites". Journal of Superhard Materials. Vol. 30, No. 6 (2008): pp. $392 \div 399$.

8. Shahzad K., Deckers J., Boury S., Nerinck B., Kruth J-P., Vlegels J. „Preparation and indirect selective laser sintering of alumina/PA microspheres". Ceramics International. Vol. 38, No. 2 (2012): pp. $1241 \div 1247$. 